\title{
EFFECTS OF PHYSICAL ACTIVITY ON COLLAGEN CONTENT IN MICE
}

\author{
Kenzo KoYama* and EijI Goto**
}

\begin{abstract}
Male mice of dd-strain, at 4 and 8 week-ages were used at the start of the trained. The trained continued for successive during 4 to 34 week-ages and 8 to 70 week-ages. The trained group was exercised on a treadmill, and the untrained group used as control under normal laboratry condition. The skin of the right dorsum near the tail was sampled and its collagen content was examined by means of concentration of hydroxyproline. The collagen content in the skin of the trained group is lower than in that of the untrained one at each week-age, 14-18, 27-34 and 63-70 week-ages. The trained group was depressed hydroxyproline concentration of defatted skin, compared with untrained one at each weekage. The continuous exercise reduced the accumulation of collagen in the skin of mice.
\end{abstract}

(J. Physical Fitness Japan 1986, $35: 177 \sim 181$ )

key words : aging, collagen content, hydroxyproline concentration, physical activity, skin

\section{Introduction}

By aging, mammalian is generally known to decrease parenchymatous cell, and to increase interstitial cell or connective tissue. The phenomenon is represented in a accumlation of collagen content. Takeda, et al. ${ }^{14)}$ have observed the collagen content in a skin gradually increased during growth and developmet. Numerous reports have clarified that the amount of collagen changes to increase in the connective tissue of several organs as the animal grows ${ }^{412 / 13 / 17}$. It is generally accepted that the collagen occur abundantly in older animals.

Recently, distribution and chain composition of various types of collagen which is a main constituent of connective tissue of animal have been extensively studied ${ }^{1 / 2) 9}$. The interstitial collagen is now divided into five types such as type I, II, III, IV and $\mathrm{V}^{3 / 9)}$. We were under- taken to see the changes of collagen content of the skin, type I collagen, in mice which were subjected to the continuous exercise of the definite duration. And we were also objected to see the effects of the exercise by means of collagen content as the indicator. Because very little is known of the effects of physical activity on the metabolism of collagen. We are imagined that the metabolism of collagen is influenced indirectly by exercise in a skin compared with a tendon and skeletal mascle, and that a skin is indicated the effects of exercise on the whole.

\section{Materials and Methods}

Male mice of dd-strain were used in this work. They were divided into two groups (trained and untrained) and reared 5 animals in one small cage $(17.5 \mathrm{~cm}$ in width, $24.5 \mathrm{~cm}$ in length and $12.5 \mathrm{~cm}$ in hight at $20^{\circ} \pm 2{ }^{\circ} \mathrm{C}$ ). When started this experiment, animals of both

\footnotetext{
* 大阪教育大学養護教室 Department of Health Science, Osaka Kyoiku University, 干547 大阪市平野区流町 1 丁目6-7 Hirano-ku, Osaka 547, Japan.

** 大阪教育大学保健学教室 Department of Health Science, Osaka Kyoiku University, Tennoji-ku, Osaka 543, Japan.
} 
groups were allowed to eat ad libitum with solids (Oriental Yeast Co., Chiba) and water. Forty-six individual of untrained group were left under this condition for the definite duration of time that corresponded with that in the trained group. Forty-six animals of trained group were subjected to the treadmill exercise program with consisted of 4 times of running at a speed of $15.8 \mathrm{~cm} / \mathrm{s}$ for $20 \mathrm{~min}$ per a week. Goto et al. ${ }^{5)}$ have reported to the running speed $(\mathrm{cm} / \mathrm{s})$ had relation to the logarithm value of all-out time. Our exercise program was determined by considering their relation and did not give the trained group a stress. The experiment was started when the animals became 4 and 8 week-ages. Mean weight of them was obtained from the all individual which have live in the day of weighting. Every individual was weighted before the training during course of the experiments each day.

At the 14, 27 and 63 week-ages of 3 animals were sacrificed for the chemical analysis. The skin of the right dorsum near the tail were taken either from 3 trained and/or 3 untrained animals after the hair was removed with scissors. About $100 \mathrm{mg}$ of a skin piece was used as the sample for each time of experiments. The collagen content of the skin was examined by means of measuring of their hydroxyproline content. It is generally known to amino acid that hydroxyproline only existed in collagen. The methods were as follows. First, the fat in the sample was extracted with a 1:1 mixture of aceton and ethyl ether in a soxhlet apparatus over a periods of 28 hours. The weight of fat-free residue of the skin was measured. Protein hydrolysate was prepared by autoclaving $10 \mathrm{mg}$ of the fat-free residue with $2 \mathrm{ml}$ of $6 \mathrm{~N} \mathrm{HCl}$ in a sealed tube for 7 hours at $1.2 \mathrm{~kg} / \mathrm{cm}^{2}$ pressure. Two $\mathrm{ml}$ of protein hydrolysate was filtered and transferred to a $25 \mathrm{ml}$ volumetric flask. After neutralized with ammonium hydroxide and it was diluted to the volum of $25 \mathrm{ml}$. The measurment of hydroxyproline concentration was carried out according to Neuman and Logan ${ }^{10)}$. The absorbancy at $560 \mathrm{~nm}$ was measured using a spectrophotometer (Hitachi Model 100-10).

\section{Results}

Mean weight of the trained and untrained group was measured every day, but they did not show any noticeable difference between. Therefore, mean weight of them shown in each week-age, when this experiment was performed (Table 1).

Table 1. Mean body weight and dry weights of defatted skin of trained and untrained groups.

\begin{tabular}{ccccc}
\hline Group & Week-ages & $\mathrm{N}$ & $\begin{array}{l}\text { Mean body } \\
\text { weight }\end{array}$ & $\begin{array}{c}\text { Dry weights of } \\
\text { defatted skin }\end{array}$ \\
\cline { 3 - 4 } & & & $\mathrm{g}$ & $\begin{array}{c}\text { mg/100 mg wet } \\
\text { weights }\end{array}$ \\
\hline \multirow{2}{*}{ Trained } & $14-18$ & 12 & $45.5 \pm 7.2$ & $33.6 \pm 6.8$ \\
& $27-34$ & 13 & $54.3 \pm 8.2$ & $20.0 \pm 3.7$ \\
& $63-70$ & 21 & $35.3 \pm 5.7$ & $34.8 \pm 4.5$ \\
\hline & $14-18$ & 13 & $51.8 \pm 4.8$ & $30.3 \pm 6.8$ \\
& $27-34$ & 13 & $55.8 \pm 7.9$ & $20.3 \pm 3.4$ \\
& $63-70$ & 20 & $35.9 \pm 6.5$ & $33.4 \pm 6.8$ \\
\hline
\end{tabular}


A standard curve prepared with 0 to $20 \mu \mathrm{g}$ of hydroxyproline. The standard curve can be expressed with a formula $\mathrm{Y}=0.023 \mathrm{x}+0.008$. Of both trained and untrained groups in each week-age the mean values of dry weight and hydroxyproline concentration of defatted skin are shown in Table 1 and Fig. 1. The dry weights of the defatted skin are shown in Table 1, which gave the slightly weighter value in trained group at 14-18 and 63-70 week-ages than in untrained one, indicating to the amount of fat of the trained group is less than that of the untrained one. Two guoups of 27-34 week-ages did not show difference between.

Hydroxyproline concentration are shown in Fig. 1 which clearly illustrated significant difference between two groups in each weekage. Hydroxyproline concentration of defatted skin ( $\mu \mathrm{g} / \mathrm{mg}$ dry weights $\pm \mathrm{SD}$ ) was $24.6 \pm 3.8$,
$17.2 \pm 2.8$ and $24.8 \pm 2.6$ at $14-18,27-34$ and $63-$ 70 week-ages, respectively, in trained group, and was $27.5 \pm 2.8,24.9 \pm 5.9$ and $28.1 \pm 1.9$ at each week-age in untrained one. The collagen content in the skin of the trained group is lower than in that of the untrained one in each week-age. Thc collagen content at 14-18 week-ages gradually decreased in two groups. Moreover, the collagen content at 27-34 to 63-70 week-ages increased in two groups. Hydroxyproline concentration of dry weight at $63-70$ week-ages in the trained group is as much as that at 27-34 week-ages in the untrained group. This result indicated that the continuous exercise reduced the accumulation of collagen content in the skin.

\section{Discussion}

Numerous studies have reported about collagen content of several organs of some ani-
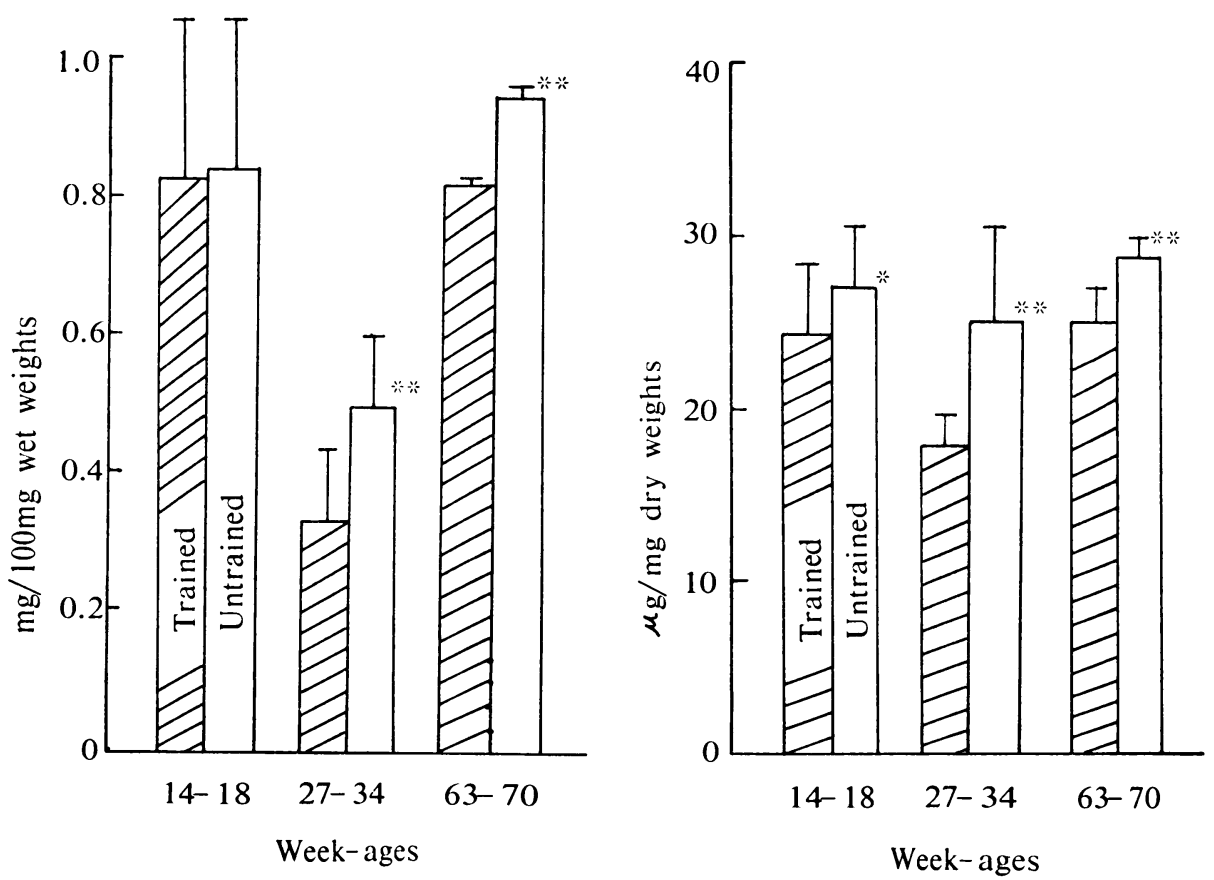

Fig. 1. Hydroxyproline concentration of defatted skin in each week-age of trained and untrained groups. Hydroxyproline concentration give significant difference in t-test. $*^{* *},{ }^{*}$; Difference from untrained group $: p<0.01, p<0.05$. 
mals. Sobel et al. ${ }^{13)}$ measured the collagen content of femurs of rats, and pointed out the increase of collagen with somatic growth. Elster and Lowry ${ }^{4}$ ) also measured the collagen content of liver, kidney, lung, heart, skeletal muscle and spleen of guinea pig, and did not observed changes of collagen in skeletal muscle and spleen. This is due to influence by a nature of collagen in each tissue. In this work, we measured the collagen content of skin in mice.

In skin collagen, Heikkinen ${ }^{6 / 7)}$ have reported to increase of collagen in rat skin with growth, and noticed that the rate of metabolism of collagen became slow after cessation of the growth. Takeda et al. ${ }^{15}$ ) showed the increase of the collagen content until 12 weekages in the male mouse skin and until 10 week-ages in female one. They pointed out that the collagen content varied with the sex. Male mice were used in our work, which sacrificed after the increase of collagen content, that is, the collagen content saw subsequent to the process of growth.

On the influence of physical activity, we showed that the mice of the trained group have less amount of the skin collagen that those of the untrained group (cf. Table 1 and Fig. 1). By subjecting rats to the define training which is comporsed of sprint and endurance, the results of Tipton et al. ${ }^{16)}$ is well consistent with that of our case. That is, the collagen content in the skin of the trained group is lower than in that of the untrained one when compares with the same age mice. This fact clearly indicate that the skin of the trained mice is younger and more fresh than the untrained one (cf. Fig. 1). These results are the difference in collagen metabolism of the skin between trained and untrained mice. Physical activity seems to depress aging of a skin.

Previous studies a five type of collagen have revealed that type I collagen is contained mainly in skin, tendon and aorta etc ${ }^{9)}$. It is necessary to study in relation the physical activity and the occurence of some other type of collagen.

In hydroxyproline concentration, dividing $\mu \mathrm{g} / \mathrm{mg}$ dry weights by $\mathrm{mg} / 100 \mathrm{mg}$ wet weights in each week-age, the results obtained the high value at 27-34 week-ages in both group. And also, dry weights of defatted skin in 2734 week-ages showed lower value than other week-ages (cf. Table 1). This difference, first, is need to consider hypodermic fat, triglyceride. Accumulation of triglyceride may influence the dry weights of defatted skin, owing to triglyceride attach to the skin. In 27-34 week-ages, the quantity of triglyceride seems to accumulate more than other week-ages. And next, it may be the participation of intercellular substance, in other word, it means that the water content is merely replaced by intercelluar substance and polysaccharide. To decrease of water content, it assume to concern in swelling of fibrous protein, i.e., collagen and elastin, and in the quantity of polysaccharide. Moreover, Heikkinen ${ }^{8)}$ have reported to decrease of water content into collagen of skin with aging. These are suggested that the water content of skin occurs the difference in each week-age. It may be need to study metabolism of hypodermic fat and the water content of tissue.

(Received, Oct. 12. 1984)

\section{References}

1) Bächinger, H. P., Bruckner, P., Timpl, R., Prockop, D. J, and Engel, J.(1980) : Folding metabolism of the triple helix in type-III collagen and type-III $\mathrm{pN}$-collagen; Role of disulfide bridges 
and peptide bond isomerization. Eur. J. Biochem. 106, 619-632.

2) Bentz, H., Bächinger, H. P., Glanville, R. W.and Kühn, K.(1978) : Physical evidence for assembly of $\mathrm{A}$ and $\mathrm{B}$ chains of human placental collagen in a single triple helix. Eur. J. Biochem. 92, 563-567.

3) Dixit, S. N.(1980) : Type-IV collagens ; Isolation and characterization of two structurally distinct collagen chains from bovine kidney cortices. Eur. J. Biochem. 106, 563-570.

4) Elster, S. K. and Lowry, E. L. (1950) : Collagen content of guinea pig tissue. Proc. Soc. Exp. Biol. Med. 75, 127-129.

5) Goto, E., Shiraishi, T. and Kambayashi, H.(1977) : Influence of physical exercise during the growth period of mice. Memoirs of Osaka Kyoiku Univ. Ser. III 26, 123-129.

6) Heikkinen, E. (1969): The ageing of conective tissue. Scand. J. Clin. Lab. Invest. 108, 6-7.

7) Heikkinen, E. and Vuori, I. (1972): Effect of physical activity on the metabolism of collagen in aged mice. Acta. Physiol. Scand. 84, 543-549.

8) Heikkinen, E. (1973) : Aging of interstitial col lagen. In ; Robert, L., Createil, S. and Karger, B. Frontiers of Matric Biology. 1 st Ed Chap. 1.

9) Kuhn, K. and Glanville, R. W. (1980) : Molecular structure and higher organization of different collagen types. In ; Viidik, A. and Vuust, J. Biology of collagen. 1 st Ed., Chap. 1, Academic press, New York and London 1-14.

10) Neuman, R. E. and Logan, M. A. (1950) : The determination of hydroxyproline. J. Biol. Chem. 184, 299-306.

11) Nutter, D. O., Priest, R. E. and Fuller, E. O. (1980) : Endurance training in rat. I. Myocardial mechanics and biochemistry. J. Appl. Physiol.: Res. Env. Exer. Physiol. 51, 934-940.

12) Sjoerdsma, A., Udenfriend, S., Keiser, H. and Leroy, C. (1965) : Hydroxyproline and collagen metabolism. Ann. Inter. Med. 63(4), 672-694.

13) Sobel, H., Marmorston, J. and Moore, F. J. (1954): Collagen and hexosamine content of femurs of rats. Proc. Soc. Exp. Biol. Med. 87, 346-349.

14) Takeda, T, Suzuki, Y., Yao, C. S. and Yamada, S. (1973) : Experimental studies on the effect of aging and sex on collagen in mice. Connective Tissue 5(2), 29-34.

15) Takeda, T., Suzuki, Y. and Yao, C. S. (1975): Experimental studies on the effect of aging and endocrine control on collagen formation in various organs. Acta. Path. Jap. 25(2), 135-151.

16) Tipton, C. M., Matthes, M. R. D. and Carey, R. A. (1975) : Hydroxyproline concentrations in ligaments from trained and nontrained rats. In; Howald, H. and Poortmans, J. R. Metabolic adaptation to prolonged physical exercise. Birkhauser Verlag Switzerland 262-267.

17) Tomanex, R. J., Taunton, C. A. and Liskop, K. S. (1972) : Relationship between age, chronic exercise and connective tissue of the heart. J. Gerontol. 1, 33-38. 